\title{
Cadmium effects and accumulation in cultures of Prorocentrum micans (Dinophyta)
}

\author{
H. Kayser ${ }^{1} \&$ K.-R. Sperling ${ }^{2}$ \\ ${ }^{1}$ Biologische Anstalt Helgoland (Litoralstation); \\ D-2282 List/Sylt, Federal Republic of Germany, \\ and \\ ${ }^{2}$ Biologische Anstalt Helgoland (Isotopenlaboratorium); \\ Wüstland 2, D-2000 Hamburg 55, Federal Republic of Germany,
}

\begin{abstract}
Effects and accumulation of cadmium were studied in unialgal 10-1 batch-culture experiments with the dinoflagellate Prorocentrum micans Ehrenberg. Tests were made using sterile filtered North Sea water enriched with nitrate and phosphate only in order to avoid disturbances by complex formation. Cadmium was added to the cultures in amounts of 100 to $0.13 \mu \mathrm{g} \mathrm{l}^{-1}$. In one series it was added at the start of the experiments and in a second one after a growth period of 1

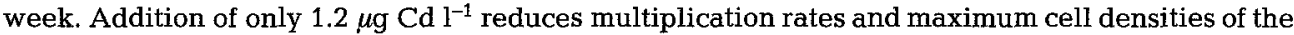
algae. Not until $0.4 \mu \mathrm{g} \mathrm{Cd}^{-1}$ does growth correspond to that of the controls. Cadmium concentrations were measured, after filtration, in the culture medium and in the biomass by means of flameless AAS. The cadmium content in algae increased from $2.7 \mu \mathrm{g} \mathrm{g}^{-1}$ (dry weight) in controls to $500 \mu \mathrm{g} \mathrm{g}^{-1}$ (dry weight) in media containing $100 \mu \mathrm{g} \mathrm{Cd} \mathrm{l}^{-1}$. Uptake occurred rapidly during the first few days of the experiments, slowed down somewhat during exponential growth stage, and increased during decay of the cultures. Cadmium content of culture media remained nearly constant (Series 1) or decreased only slowly during experimental time (Series 2). The highest concentration factor was measured in the controls. It decreased with increasing metal concentration in the medium and increased with experimental time. Structural modifications of the cells were visible after Lugol fixation only, indicating brittleness of the cell walls. P. micans has shown to be extremely sensitive to cadmium and to accumulate this metal.
\end{abstract}

\section{INTRODUCTION}

Cadmium is a very common waste component which is highly toxic to plants, animals and man (Varma \& Katz, 1976; Yamagata, 1978). Thus, many investigations on lethal and sublethal effects of this metal on marine organisms have already been undertaken (e. g. Hoppenheit \& Sperling, 1977; v. Westernhagen et al., 1978; Markham et al., in press). As most such studies have concentrated on individuals at certain stages of life history it seems to be meaningful to add, as in the paper presented, some experiments at the population level. Impairment at this level would have a serious impact on the whole ecosystem of polluted areas. Furthermore, attention must not only be paid to toxicity, but also to the bioaccumulation of cadmium in aquatic organisms (e.g. Dethlefsen, 1977/78; and the literature cited therein).

As most of the accumulation and toxicity studies on marine organisms concentrate on higher trophic levels only systematic studies exist about the impact of cadmium on 
primary producers. These mainly consisted of small-scale laboratory experiments with cadmium concentrations far above the levels to be expected in polluted areas. Furthermore, other authors used different experimental conditions, often using chelators or soil extracts in their media, which may influence toxicity and uptake of cadmium. This would appear to explain why results varied in a wide range as is shown in literature reviews by Taylor (1977), Davies (1978) and Leland (1978). To avoid such difficulties, we enriched the test medium (sterile filtered North Sea water) with phosphate and nitrate only. We considered this as an essential precondition for the observation of effects at realistic $\mathrm{Cd}$ concentrations. In the German Bight these concentrations range from 0.018 (Sperling, unpublished) and 0.02-0.05 (Kremling, personal communication) to $0.15 \mu \mathrm{g}$ $\mathrm{Cd} \mathrm{l}^{-1}$ (Schmidt, 1976). In some nearshore coastal waters, however, levels of 4.9 (Bristol Channel) and $5.8 \mu \mathrm{g} \mathrm{Cd}^{-1}$ (Severn Estuary - Bryan, 1976) have been found.

The dinoflagellate Prorocentrum micans Ehrenberg, tested in the experiments presented, is a common North Sea plankton species and has already been proved to be very sensitive to other heavy metals like $\mathrm{Hg}$ and $\mathrm{Zn}$ (Kayser, 1976, 1977). In a first series Cd $\left(0.13-100 \mu \mathrm{g} \mathrm{l}^{-1}\right)$ was added immediately at the start of the experiments. In a second series (3.7-100 $\mu \mathrm{g} \mathrm{Cd}^{-1}$ ) it was added 1 week after inoculation in order to investigate possible effects of organic substances released from the algae into the medium.

\section{MATERIALS AND METHODS}

The dinoflagellate Prorocentrum micans Ehrenberg was isolated near Helgoland and cultivated in non-axenic monocultures using a medium of natural seawater from List, Sylt (29 $\pm 1.5 \% \mathrm{~S}$, sterile filtered through Millipore filters of $0.22-\mu \mathrm{m}$ pore diameter). Stock cultures were kept in $\mathrm{f} / 2$ medium (Guillard \& Ryther, 1962). In cadmium experiments culture medium was pure seawater enriched only with $0.075 \mathrm{~g} \mathrm{NaNO}_{3}$ and $0.005 \mathrm{~g} \mathrm{NaH}_{2} \mathrm{PO}_{4} \cdot \mathrm{H}_{2} \mathrm{O}$ per litre. The first inoculation was from stock cultures which had been transferred for at least 2 batch-culture periods to only $\mathrm{N}$ - and $\mathrm{P}$-enriched seawater medium in order to avoid the transfer of $f / 2$ nutrients into the test medium. Further inocula followed from control cultures during exponential growth phase. The algae were cultivated in series of 10-1 glass bottles (Jenaer Glas, DURAN 50). Before use the bottles were washed thoroughly with $\mathrm{HNO}_{3}$, rinsed with bidistilled water and pretreated twice with culture medium containing the same initial $\mathrm{Cd}$ concentration as in the following experiments; this saturated the glass walls. The metal was added in amounts of 0.13 to $100 \mu \mathrm{g} \mathrm{l}^{-1}$ from a stock solution (1.6308 $\mathrm{g} \mathrm{CdCl}_{2}-$ Baker - in 11 bidistilled water). The medium was not changed during the experiment.

In order to preclude any effects of cadmium residues from the glass walls of bottles which were used repeatedly in separate experimental series, a number of 8 control cultures was set up in culture vessels, washed twice with $\mathrm{HNO}_{3}$ and rinsed with bidistilled water, which had been used previously in experiments with a concentration of $100 \mu \mathrm{g} \mathrm{Cd} \mathrm{l}^{-1}$. The results showed that there was no "bottle residue effect" on the growth of algae. By way of precaution, however, the experiment with $1.2 \mu \mathrm{g} \mathrm{Cd} \mathrm{l}^{-1}$ was run in thoroughly cleaned new bottles.

The cultures were set up in constant-temperature rooms at $18 \pm 1{ }^{\circ} \mathrm{C}$. The bottles were illuminated by laterally-positioned daylight fluorescent lamps (Osram- L40 W/50) with a light intensity of about 3,000 Lux. The distance from the light source to the bottles 
was $10 \mathrm{~cm}$. A 14:10 h light:dark period was maintained. To effect a homogeneous distribution of the algae slight turbulence of the culture medium was obtained by aeration (coarse bubbles, $40 \mathrm{ml}$ air $\mathrm{min}^{-1}$ ) through a glass capillary.

Growth rates, cell production and morphological alterations of the cells were observed in order to evaluate the effects of cadmium. Cell counts were made with an inverted microscope. Samples were taken daily or in some cases at longer intervals. Sampling took always place at a fixed time of the day $(10.00 \mathrm{~h})$. Each series was repeated fivefold and accompanied by 3 controls.

The cadmium content of the cells was determined with a flameless AAS. For this purpose quotas of 200 to $1,500 \mathrm{ml}$ of the cultures were filtered (Millipore; $0.45-\mu \mathrm{m}$ pore diameter) at the start of the experiments and on the 1st, 3rd, 7th, 14th, 21st and 28th days. The cells were washed on the filters with uncontaminated seawater in order to remove cadmium residues from the culture medium, scraped off carefully from the filters and transferred into 1.5-ml cadmium-free Eppendorf-micro test tubes. After drying (at $60^{\circ} \mathrm{C}$ overnight) the cadmium content was determined by the method of Sperling et al. (1977). The cadmium concentrations in the culture media were determined after filtration by the method of Sperling (1977). Below a concentration of $3.7 \mu \mathrm{g} \mathrm{Cd} \mathrm{l^{-1 }}$ flameless AAS measurements had to be combined with APDC extraction (Sperling, 1978).
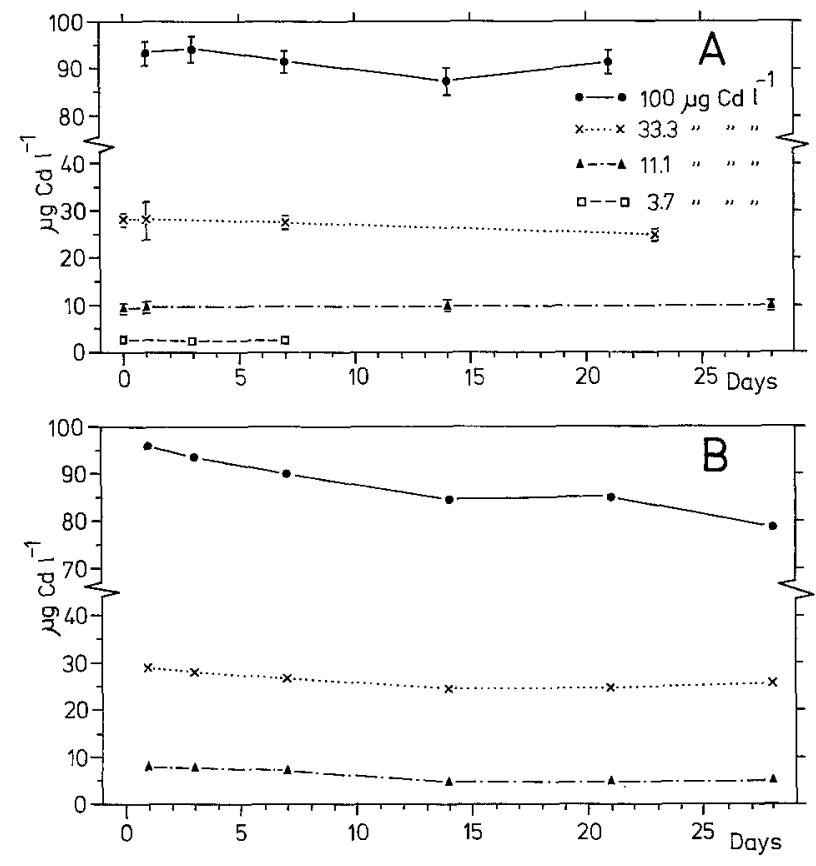

Fig. 1. Prorocentrum micans. Cadmium content of the culture media: (A) Series in which Cd was

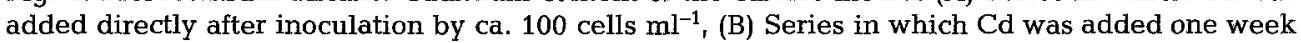
after inoculation (cell density then: ca. 1,150 cells ml-1) 


\section{RESULTS}

\section{Cadmium content of the culture media}

The standard cadmium content of $\mathrm{N}$ - and P-enriched seawater media for controls was $0.11 \pm 0.075 \mu \mathrm{g} \mathrm{l}^{-1}(\mathrm{n}=27)$. In cadmium-enriched media the recovered levels were about 10 to $15 \%$ lower than intended. In the series with addition of the metal immediately at the beginning of the experiments, levels remained relatively constant during experimental time: At $100 \mu \mathrm{g} \mathrm{Cd} \mathrm{l}^{-1}$ a mean value of $91 \pm 3.5 \mu \mathrm{g} \mathrm{l}^{-1}$ was recovered (Fig. 1A); during the first 14 days of the experiment only a slight decrease of this concentration was observed. At $33.3 \mu \mathrm{g} \mathrm{l}^{-1}$, the recovered Cd levels in the medium were $28.4 \pm 1.2 \mu \mathrm{g} \mathrm{l}^{-1}$ at the start and $25 \pm 0.7 \mu \mathrm{g} \mathrm{l}^{-1}$ at the end of the experiments. At 11.1 and $3.7 \mu \mathrm{g} \mathrm{Cd} \mathrm{l}^{-1}$ the content of the media remained relatively constant at $9.92 \pm 0.7$ and $2.8 \pm 0.4 \mu \mathrm{g} \mathrm{Cd} \mathrm{l}^{-1}$, respectively. In the series with addition of cadmium 1 week after the start of the experiments the metal content of the culture media (Fig. 1B) decreased somewhat more than in the foregoing series. At addition of $100 \mu \mathrm{g} \mathrm{Cd} \mathrm{l}^{-1}$ the recovered concentrations were $96 \mu \mathrm{g} \mathrm{l}^{-1}$ after the 1st day and $79 \mu \mathrm{g} \mathrm{l}^{-1}$ at the end of the experiment. At addition of 33.3 and $11.1 \mu \mathrm{g} \mathrm{Cd}^{-1}$ values decreased from 29.2 and 8.2 to about 25 and $5 \mu \mathrm{g} \mathrm{l}^{-1}$, respectively, during the first 14 days; values remained nearly constant at these levels for the following 2 weeks.

\section{Inhibition of growth}

\section{Addition of cadmium at the beginning of the experiments}

In control cultures Prorocentrum micans reached a mean doubling time of about 1.9 days during the exponential stage; the cell density increased from $100 \mathrm{cells} \mathrm{m}^{-1}$ to about $12,000 \pm 4,500$ cells ml ${ }^{-1}$ within 28 days (Figs 2,3 , and 5). The addition of $100 \mu \mathrm{g} \mathrm{Cd}^{-1}$ caused an initial lag phase of 1 day; then cell density increased during exponential growth to about 1,250 cells ml-1 at the 8th day of the experiment. Growth stopped at this point and cell number decreased to about $370 \mathrm{cells} \mathrm{ml}^{-1}$ on the 21st day (not shown). At lower cadmium concentrations the growth depression was even more distinct: after addition of $33.3 \mu \mathrm{g} \mathrm{l}^{-1}$ the cell numbers grew slowly to a maximum of only $800 \mathrm{cells} \mathrm{ml}^{-1}$ and stagnated at this level (Fig. 2). Addition of 11.1 and $3.7 \mu \mathrm{g} \mathrm{Cd}{ }^{-1}$ caused, after a maximum of 600 and 300 cells ml ${ }^{-1}$, a decrease to about 260 and 125 cells ml ${ }^{-1}$, respectively. Even addition of $1.2 \mu \mathrm{g} \mathrm{Cd} \mathrm{l}^{-1}$ caused decreased growth which led to a final mean cell number of only 750 cells ml ${ }^{-1}$ (compared with 12,000 cells ml $^{-1}$ of the controls). Separate cultures, however, showed unusual variations between 60 and 2,250 cells ml ${ }^{-1}$ at the end of the experiment (Fig. 2). Finally, addition of $0.4 \mu \mathrm{g} \mathrm{Cd} \mathrm{l}^{-1}$ (Fig. 3) and $0.13 \mu \mathrm{g}$ $\mathrm{Cd}^{-1}$ (not shown) had no visible effect on division rate and maximum cell number for a period of 29 days.

Maximum and final cell densities of the cultures at various Cd concentrations in the media are summarized in Figure 4A. The results show that the effect of $\mathrm{Cd}$ was mostly distinct after addition of $3.7 \mu \mathrm{g} \mathrm{l}^{-1}$. After addition of $1.2 \mu \mathrm{g} \mathrm{Cd}^{-1}$ the division rate of the algae was reduced to a mean doubling time of 5.4 days for the first 10 days (1.9 days in controls, Fig. 2). In controls cells divided 7 times during the experiment; after addition of $3.7 \mu \mathrm{g} \mathrm{Cd}^{-1}$ this rate was reduced to 1.5 times. 


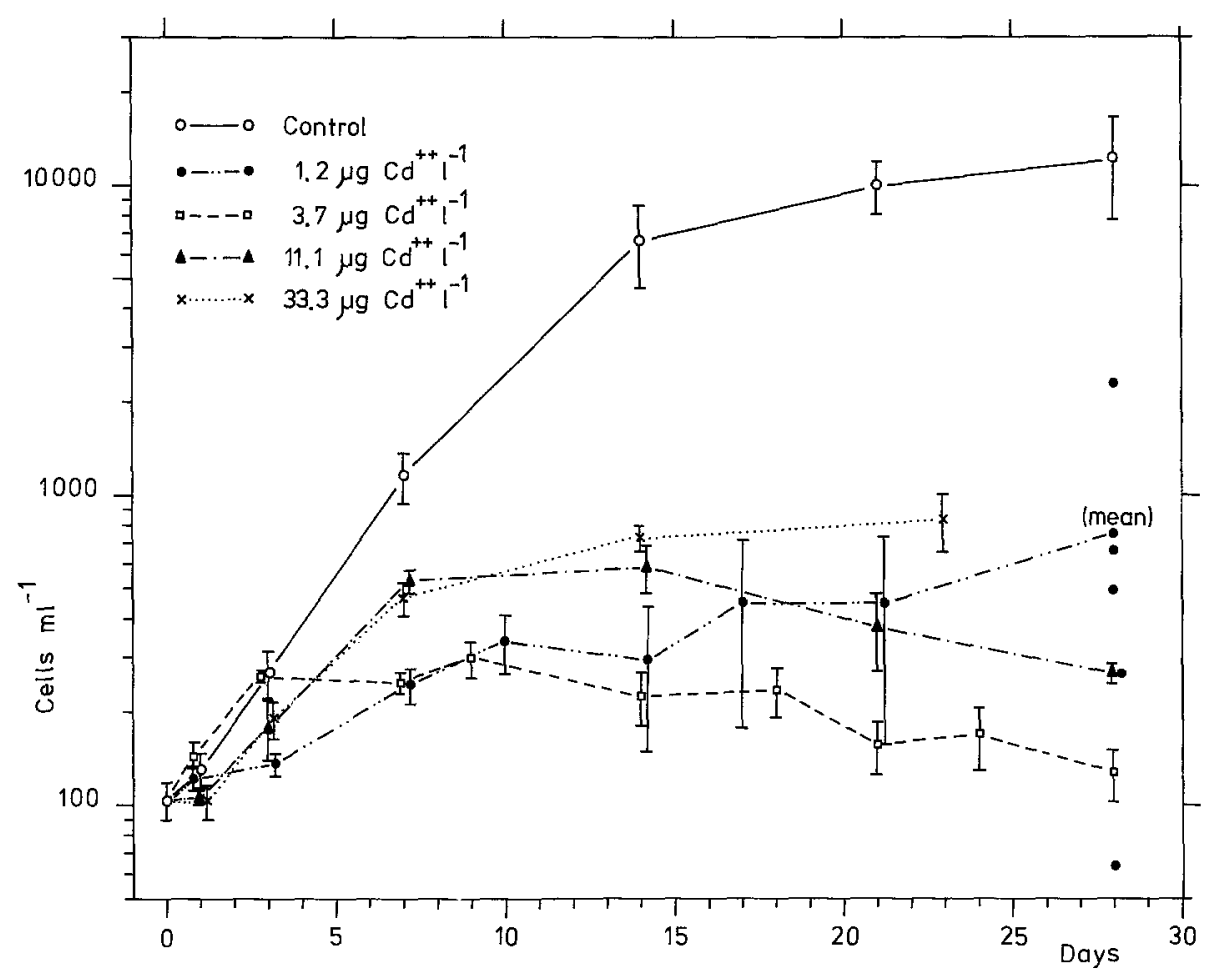

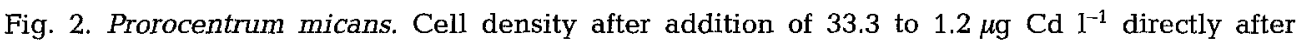
inoculation. Mean values and standard deviations are given from every 5 replicates and a total of 17 controls

Addition of cadmium one week after the start of the experiments

In all cultures the cell density increased during the first week but division rate decreased with increasing cadmium concentrations (Fig. 5). Maximum cell densities amounted to about 14,000 cells $\mathrm{ml}^{-1}$ in controls whereas maximum cell densities of only 6,400 and 4,300 cells ml $^{-1}$ were obtained after addition of 3.7 and $100 \mu \mathrm{g} \mathrm{Cd} \mathrm{l}{ }^{-1}$, respectively. At the end of the experiments the corresponding cell densities were only 2,300 and 750 cells $\mathrm{ml}^{-1}$. The results are summarized in Figure $4 \mathrm{~B}$ (maximum and final cell densities of the cultures versus Cd concentrations in the media). Growth inhibition increased with increasing cadmium concentrations. After addition of the metal, cells divided 3.6 times in controls, 2.5 times at $3.7 \mu \mathrm{g} \mathrm{l}^{-1}$ and 1.9 times at $100 \mu \mathrm{g} \mathrm{l}^{-1}$.

\section{Morphological alterations of the cells}

The only morphological alterations to be found directly were irregular deformations of cells of decreasing cultures at higher cadmium concentrations. After Lugol fixation, however, in cadmium-treated cells a vesicular sinus of the protoplast was observed occasionally which protruded over the far end of the armour. These bladders occurred 


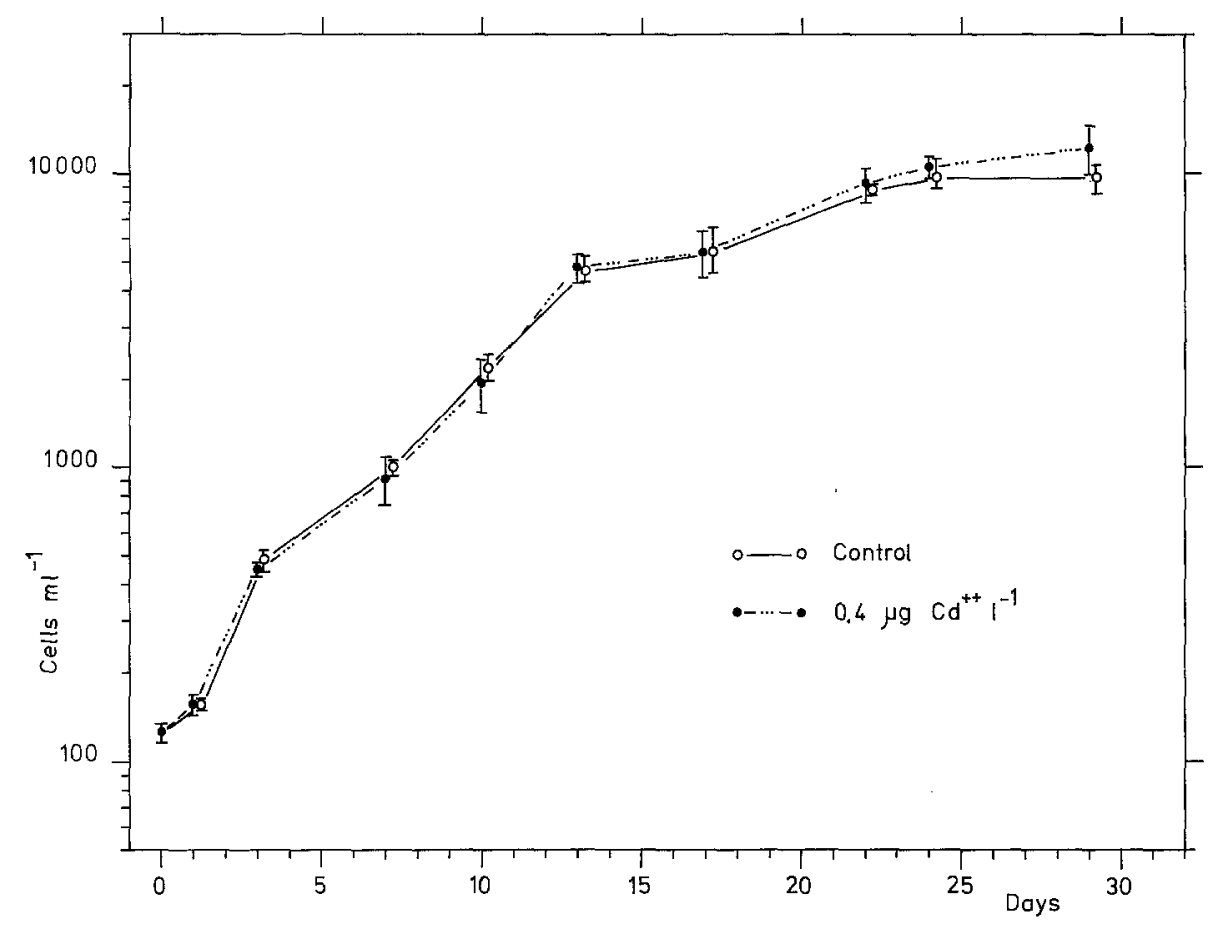

Fig. 3. Prorocentrum micans. Cell density after addition of $0.4 \mu \mathrm{g} \mathrm{Cd}^{-1}$ directly after inoculation. Mean values and standard deviations are given from 5 replicates

mainly after addition of 100 and $33.3 \mu \mathrm{g} \mathrm{Cd}^{-1}$ on the $3 \mathrm{rd}$ day, and at $11.1 \mu \mathrm{g} \mathrm{Cd}^{-1}$ on the 7 th day of the experiments, and their frequency increased. with time. In controls corresponding formations have only rarely been observed.

\section{Cadmium accumulation}

\section{Addition of cadmium at the beginning of the experiments}

The standard cadmium content in cells of stock and control cultures was determined in 132 separate samples and amounted to a mean value of $2.66 \pm 1.32 \mu \mathrm{g} \mathrm{g}^{-1}$ dry weight (Fig. 6). After addition of $100 \mu \mathrm{g} \mathrm{Cd}^{-1}$ this value increased rapidly to $48.3 \pm 3.1$ and $85 \pm 30 \mu \mathrm{g} \mathrm{g}^{-1}$ dry weight after the 1st and 3rd days of the experiment, respectively. After this period reduced uptake led to a concentration of $99 \pm 6 \mu \mathrm{g} \mathrm{Cd}^{-1}$ dry weight on the 8th day. This date corresponds with the end of the exponential growth stage of the cultures. During the following decrease of the cell density, however, cadmium content rapidly increased anew to $284 \pm 44$ and $348 \pm 30 \mu \mathrm{g} \mathrm{Cd} \mathrm{g}^{-1}$ dry weight on the 14 th and 21st days, respectively (not shown). After addition of $33.3 \mu \mathrm{g} \mathrm{Cd} \mathrm{l}^{-1}$, cadmium content of the cells likewise increased very rapidly to $67 \pm 12 \mu \mathrm{g} \mathrm{Cd} \mathrm{g}^{-1}$ dry weight during the first 3 days (Fig. 6); then $96.3 \pm 15.5 \mu \mathrm{g} \mathrm{Cd} \mathrm{g}^{-1}$ dry weight were reached at the end of the experiment on the 23rd day. Cell density stagnated at this time (Fig. 2) without the

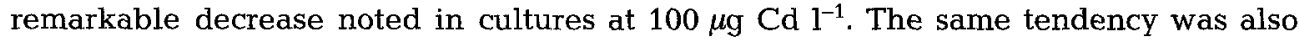


Cadmium accumulation in Prorocentrum micans
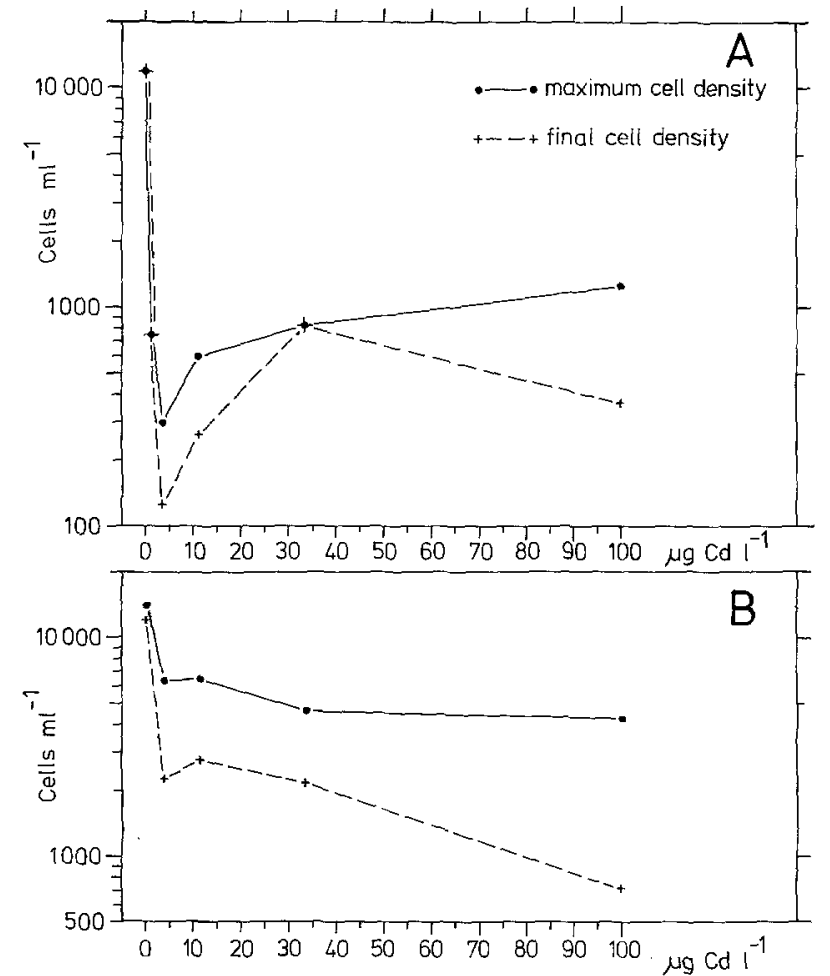

Fig. 4. Prorocentrum micans. Maximum and final cell densities of the cultures after addition of cadmium (A) directly at inoculation and (B) one week after inoculation

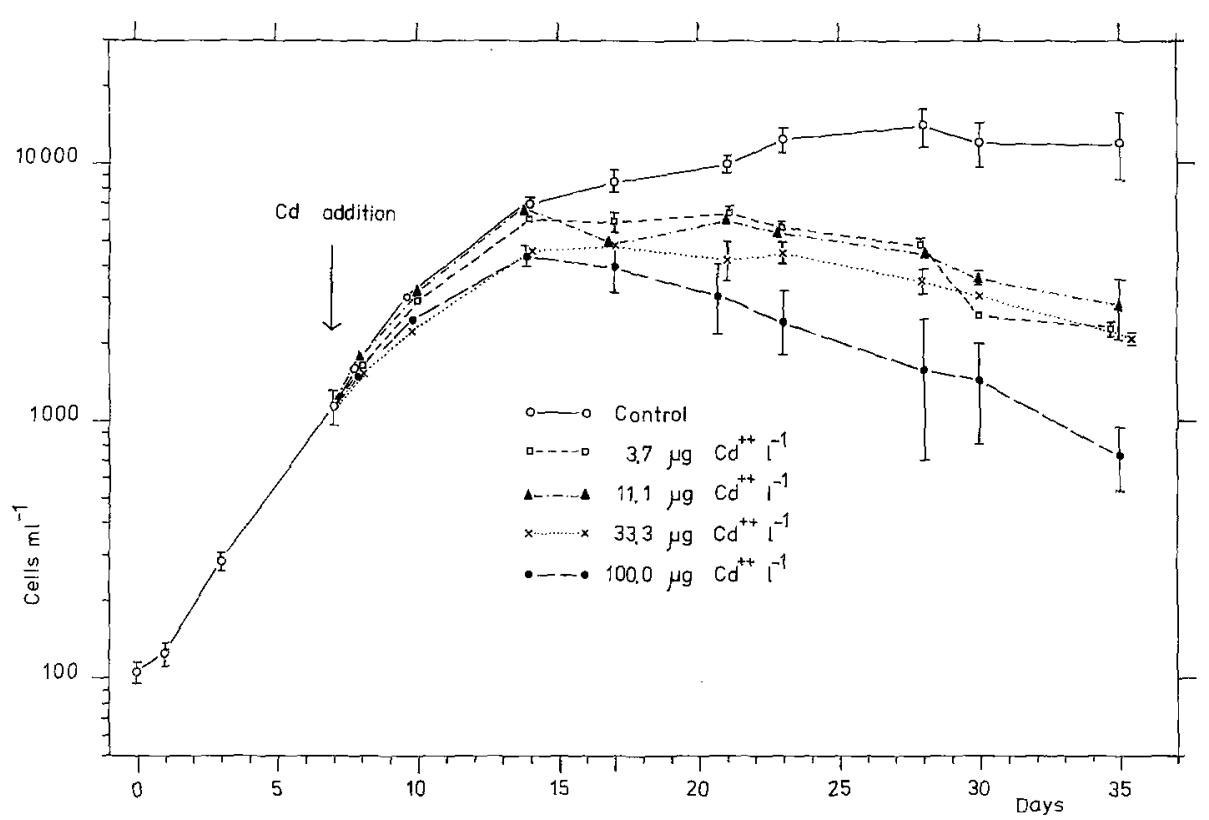

Fig. 5. Prorocentrum micans. Cell density in a series in which 100 to $3.7 \mu \mathrm{gd} \mathrm{l}^{-1}$ were added one week after inoculation 


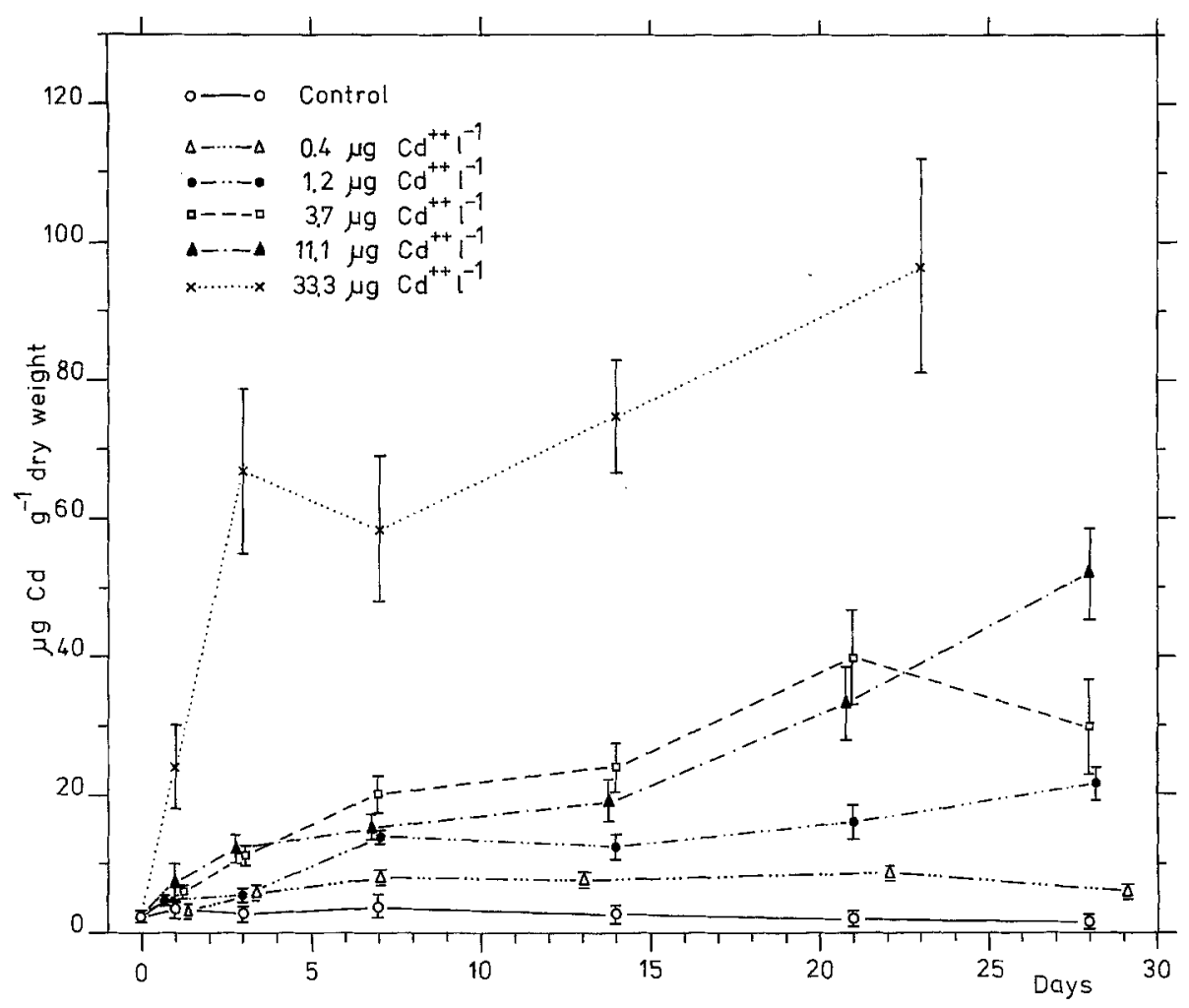

Fig. 6. Prorocentrum micans. Cadmium uptake by the cells after addition of 33.3 to $0.4 \mu \mathrm{g} \mathrm{Cd} 1^{-1}$ directly after inoculation. Mean values and standard deviations are given from every 5 replicates and a total of 20 controls

observed at lower cadmium concentrations from 11.1 to $1.2 \mu \mathrm{g}^{-1}$ (Fig. 6) and led to a

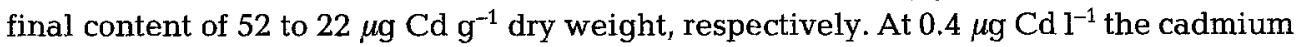
content of the cells increased to $8.2 \pm 0.4 \mu \mathrm{g} \mathrm{Cd} \mathrm{g}^{-1}$ dry weight after a period of 1 week

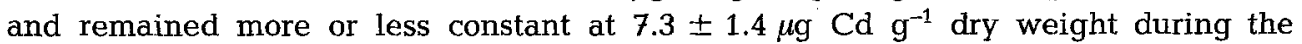
following time (Fig. 6). This was 3 times the level of uncontaminated algae.

Addition of cadmium one week after the start of the experiments

After addition of $100 \mu \mathrm{g} \mathrm{I^{-1 }}$ the cadmium content of the cells increased very rapidly from 2.66 to $76 \mu \mathrm{g} \mathrm{g}^{-1}$ dry weight within the first 3 days (Fig. 7). Ca. $95 \mu \mathrm{g} \mathrm{Cd} \mathrm{g}{ }^{-1}$ dry weight were reached after 1 week, when the exponential growth stage came to an end (Fig. 5). During the following phase of decrease the cadmium content of the cells rose rapidly to $500 \mu \mathrm{g} \mathrm{g}^{-1}$ dry weight at the end of the experiment. Similarly at 33.3 and

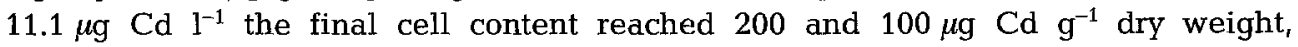
respectively. At lower concentrations the cadmium increase with time was nearly linear for the first 3 weeks and reached a saturation level for the last week. After addition of $3.7 \mu \mathrm{g} 1^{-1}$ the cadmium content in algae increased 18 times the natural level after 28 days 


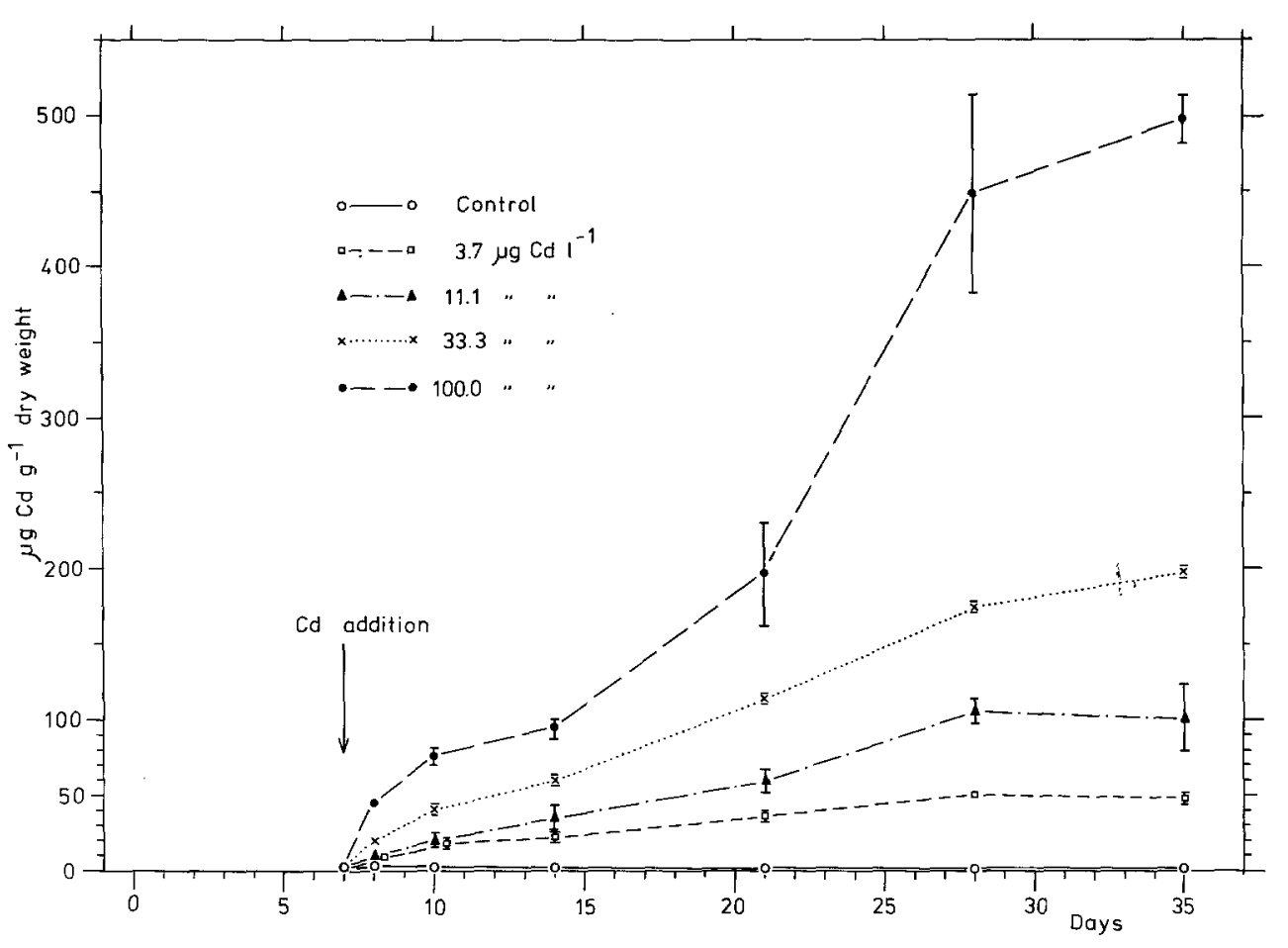

Fig. 7. Prorocentrum micans. Cadmium uptake by the cells in a series in which 100 to $3.7 \mu \mathrm{g} \mathrm{Cd} \mathrm{l^{-1 }}$ were added one week after inoculation

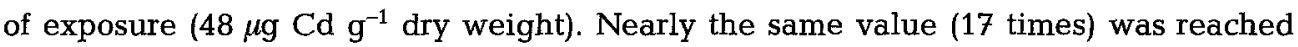
after addition of $100 \mu \mathrm{g} \mathrm{Cd}^{-1}$ even on the first day of the experiment; after 28 days of exposure, an increase of 187 times was recorded (500 $\mu \mathrm{g} \mathrm{Cd} \mathrm{g}^{-1}$ dry weight).

\section{Concentration factor}

The concentration factor of cadmium (cadmium content in the cells $\left[\mu \mathrm{g} \mathrm{kg}^{-1}\right.$ wet weight] divided by its actual concentration determined in the test water $\left[\mu \mathrm{g} \mathrm{l}^{-1}\right]$ is demonstrated in Figure 8. For wet weight calculation an average water content of $63 \%$ was determined in Prorocentrum micans. As average cadmium content of control cells was $985.2 \mu \mathrm{g} \mathrm{kg}^{-1}$ wet weight and the metal concentration in control media about $0.1 \mu \mathrm{g}$ $\mathrm{I}^{-1}$ the concentration factor amounts in this case to 9,852. At increasing cadmium concentrations the factor lowered (e. g. to 11 at the start of the experiment at $100 \mu \mathrm{g} \mathrm{Cd}$ $\mathrm{l}^{-1}$ ). The factor increased with time but values remained smaller than that of the controls at all concentrations tested. In the series with addition of cadmium 1 week after the start of the experiments (Fig. 8B) the concentration factors increased to somewhat higher values than in the series with addition of the metal immediately at the beginning of the 

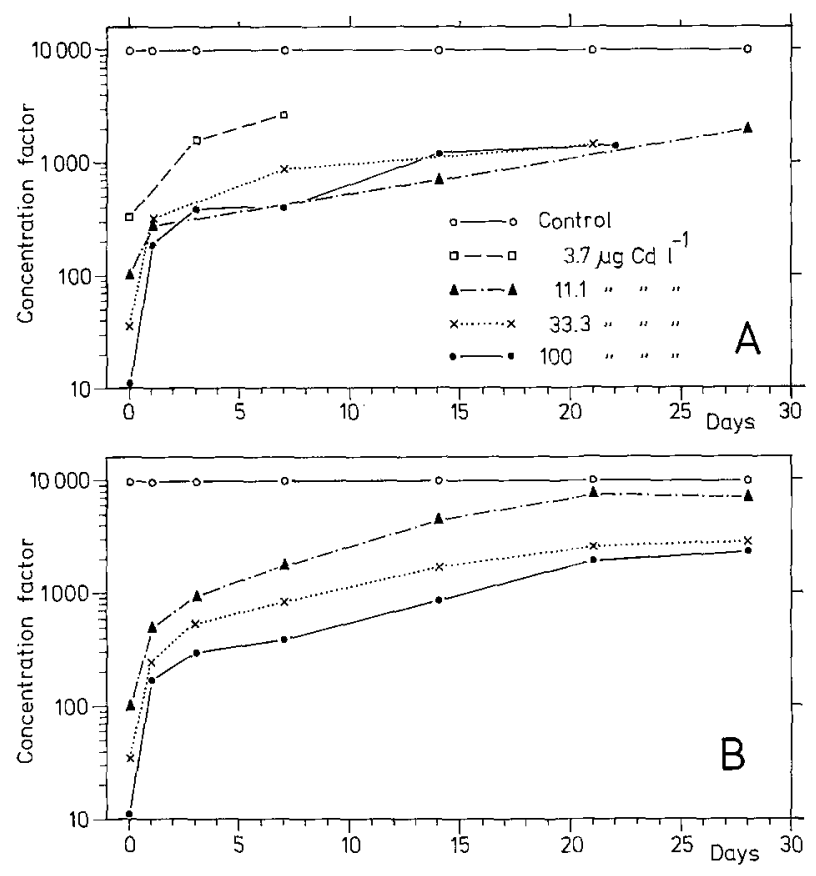

Fig. 8. Prorocentrum micans, Concentration factor (cadmium content in the organisms $\left[\mu \mathrm{g} \mathrm{Cd} \mathrm{kg}{ }^{-1}\right.$

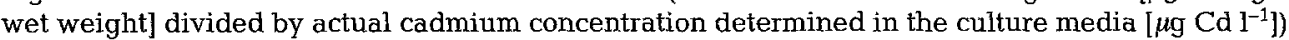
after addition of cadmium (A) directly at inoculation and (B) one week after inoculation

experiments (Fig.8A); the curves of Figure 8B show a more differentiated course with respect to the various $\mathrm{Cd}$ concentrations than that of Figure $8 \mathrm{~A}$.

\section{DISCUSSION}

The standard cadmium content of $\mathrm{N}$ - and P-enriched media in control cultures was $0.11 \pm 0.075 \mu \mathrm{g} \mathrm{l}^{-1}$; extreme care must be taken at these concentrations and the relatively large standard deviation may have arisen from unintentional contamination during experimental work. In cadmium-enriched media recovered levels were about $15 \%$ lower than intended. Such losses have been observed likewise by Rosenthal \& Sperling (1974), Klöckner (1978) and Markham et al. (1980) and as standards for measurement were prepared in exactly the same way the effect may have been caused by adsorption of $\mathrm{Cd}$ to glass walls or organic compounds of the medium. During experimental time, the cadmium content of the media remained relatively constant; comparatively small quotas of the available metal have been incorporated by the algae themselves. A rough calculation shows that, for example, only $0.8 \%$ of the total cadmium content of the culture medium had been incorporated by the algae during the first 14 days after the addition of $100 \mu \mathrm{g} \mathrm{Cd} \mathrm{l}^{-1}$ at the beginning of the experiments. The cadmium content in the cells was $284 \mu \mathrm{g} \mathrm{g}^{-1}$ dry weight at that time. The slight increase of the cadmium content of the medium during the last week of this experiment (Fig. 1 A) may be due to the remarkably decreasing cell number ( 370 cells $\mathrm{ml}^{-1}$ on the 21 st day): 
probably, decomposing cells released their cadmium content into the medium. After addition of $0.13,0.4$ and $1.2 \mu \mathrm{g} \mathrm{Cd} \mathrm{l}^{-1}$, the data from chemical analyses in the medium have not been reported. This range has unexpectedly been reached and unintentional contaminations which are tolerable at higher concentrations led to variations of the results which made the measurements meaningless then. In future work it is intended to complement these experiments using more suitable cultural and sampling methods.

With respect to other forms of dinoflagellates Berland et al. (1976) reported sublethal toxicity thresholds in growth experiments with Amphidinium carteri and Exuviella mariae-lebouriae to levels of 25 and $50 \mu \mathrm{g} \mathrm{Cd}^{-1}$, respectively; in photosynthesis tests

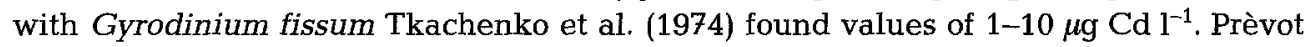
$\&$ Soyer (1978) reported growth effects in Prorocentrum micans first after addition of $5 \mu \mathrm{g}$ $\mathrm{Cd}^{-1}$. The results presented here show, however, that this latter species is much more

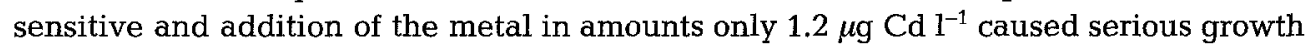
inhibition during the exponential stage of the algae. Not until addition of $0.4 \mu \mathrm{g} \mathrm{Cd} \mathrm{I}^{-1}$ did growth correspond to that of control cultures. This result may be due to an experimental design: Prèvot \& Soyer (1978) used media enriched with soil extracts. The added cadmium may then have been bound in a complex form and the part available to the organisms may have been lowered at these conditions. Although this assumption cannot be proved by the present experiments because the quotas of free and bound cadmium ions have not been determined separately, we used media enriched with nitrates and phosphates only in order to minimize complexation of the added metal already at the start of the experiments. Furthermore, the relatively low initial cell densities obtained during the series with addition of the metal at the beginning of the experiments constitute a fortunate ratio between biomass and culture medium. It is to be assumed that these conditions are essential for the observation of effects at low concentrations.

In the present experiments a difference in growth response was observed with respect to the point of the cadmium addition. When the metal was added at the start of the experiments at relatively low initial cell densities, growth inhibition was most

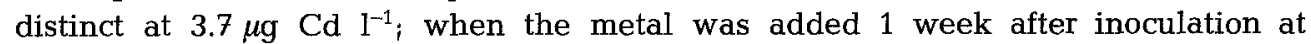
considerably greater cell numbers, inhibition occurred more regularly and $100 \mu \mathrm{g} \mathrm{Cd} \mathrm{l}^{-1}$ caused the most visible retardation. This result suggests the following explanations: (a) The higher cell density in the second series offers advantages to the population for selection processes and, thus, recovery. In the first series no indications of recovery have been found. (b) Released organic materials at higher population density 1 week after inoculation in the second series may have inactivated a considerable part of the cadmium by complexation. The generally higher growth inhibition in the first series supports this theory. As the relation between culture water and biomass is extremely high this effect is mainly to be expected at the lowest concentration of the metal in the medium. (c) In the first series the experimental subseries began with $100 \mu \mathrm{g} \mathrm{Cd}^{-1}$ and progressed to lower and lower concentrations. In each case the controls of the previous subseries had been used for inoculation of the following experiment. Although the behaviour of the controls showed no significant changes, it cannot be fully excluded that in only $\mathrm{N}$ - and P-enriched seawater media the internal nutrient status of the cells was lowered during the course of the following subseries. This fact possibly increased the sensitivity of the cells to additional environmental stressors during experimental time. In the second series the subseries with different $\mathrm{Cd}$ concentrations ran simultaneously. 
Further examinations will explore the extent to which the nutrient status of the cells may influence the sensitivity of the algae.

The standard cadmium content in control cells amounted to about $2.7 \mu \mathrm{g} \mathrm{g}^{-1}$ dry weight which corresponds to data of Bryan (1974), who reported a mean of $2 \mu \mathrm{g} \mathrm{g}^{-1}$ (dry weight) in phytoplankton. Cd exposure caused a very rapid increase of its content in the biomass during the first days. This may be due to adsorption to the cell surface (Cossa, 1976; Kremling et al., 1978). During the subsequent exponential growth phase the uptake rate decreases significantly indicating a relation with the division rate of the cells which produce new algal matter. During this period, however, cadmium may have been incorporated into the cells to such a degree that their metabolism was inhibited. Cultures stagnated in density or decreased, therefore, and cadmium content of the cells rapidly increased anew. Damaged and dead cells seem to accumulate cadmium to a higher degree. Corresponding results have been reported by Mang \& Tromballa (1978) who interpreted these findings as a consequence of a breakdown of the protective abilities of the cell walls in dying cells. A favoured uptake of cadmium by cell walls was found by Rosenthal \& Sperling (1974) when they examined herring eggs before and after spawning.

The concentration factor of cadmium was highest in controls, decreased with increasing metal content in the medium and increased during exposure time. Nevertheless the uptake of $\mathrm{Cd}$ was highly dependent on its concentration in the water. This is the typical pattern of weak ion-exchange behaviour: Saturation depends strongly on the concentration of the metal available. Concentration factors reported by other authors are in a similar range (e. g. 350-6,000 in planktonic algae, as reported by Klass et al., 1974, and Yamagata, 1978). Canterford et al. (1978) showed decreasing factors with increasing metal concentrations in the medium in experiments with the diatom Ditylum brightwel1ii. This indicates that the main binding sites of different species are not very specific but were more or less similar to each other.

Morphological aberrations could only be noted in Lugol-fixed cell samples. Corresponding observations have been shown by Prèvot \& Soyer (1978), indicating a brittleness of the cell membrane in cadmium-affected cells. This seems to be a general effect of $\mathrm{Cd}$ as a similar result has also been obtained by Rosenthal \& Sperling (1974) and Rosenthal \& Alderdice (1976) for herring eggs. Silverberg (1976) reported cadmiuminduced ultrastructural changes in mitochondria of freshwater green algae and considered the mitochondria as the primary target for cadmium-associated cytotoxicity.

A survey of the literature on the effects of cadmium on marine organisms reveals that prorocentrum micans is one of the most sensitive forms. Growth retardation in culture experiments occurs at concentrations which are reported likewise from polluted areas of nearshore coastal waters. Furthermore, the results demonstrate the extent to which response to certain $\mathrm{Cd}$ concentrations depends on the experimental design. A full assessment of the ecological consequences is impossible at present but considering the fact that the toxicity thresholds in marine organisms vary between $10 \mathrm{mg} \mathrm{Cd} \mathrm{l}^{-1}$ in lethal tests and $1 \mu \mathrm{g} \mathrm{Cd} \mathrm{l}^{-1}$ in sublethal tests, the whole concept of so-called "safety factors" may be questioned.

Acknowledgements. We gratefully acknowledge the technical assistence of Mss. U. Baber, B. Bahr, A. Priebusch and P. Siebert. 


\section{LITERATURE CITED}

Berland, B. R., Bonin, D. J., Kapkov, V. I., Maestrini, S. Y. \& Arlhac, D. P., 1976. Action toxique de quatre métaux lourds sur la croissance d'algues unicellulaires marines. - C. r. hebd. Séanc. Acad. Sci., Paris (D) 282, 633-636.

Bryan, G. W., 1976. Heavy metal contamination in the sea. In: Marine pollution. Ed. by R. Johnston. Acad. Press, London, 185-302.

Canterford, G. S., Buchanan, A. S. \& Ducker, S. C., 1978. Accumulation of heavy metals by the marine diatom Ditylum brightwellii (West) Grunow. - Aust. J. mar. Freshwat. Res. 29, $613-622$.

Cossa, D., 1976. Sorption du cadmium par une population de la diatomée Phaeodactylum tricornutum en culture. - Mar. Biol. 34, 163-167.

Davies, A. G., 1978. Pollution studies with marine plankton: Part II. Heavy metals. - Adv. mar. Biol. 15, 381-508.

Dethlefsen, V., 1977-1978. Uptake, retention and loss of cadmium by brown shrimp (Crangon crangon). - Meeresforsch. 26, 137-152.

Guillard, R. R. L. \& Ryther, J. H., 1962. Studies of marine planktonic diatoms. I. Cyclotella nana Hustedt and Detonula confervacea (Cleve) Gran. - Can. J. Microbiol. 8, 229-239.

Hoppenheit, M. \& Sperling, K.-R., 1977. On the dynamics of exploited populations of Tisbe holothuriae (Copepoda, Harpacticoidae). IV. The toxicity of cadmium: Response to lethal exposure. - Helgoländer wiss. Meeresunters. 29, 328-336.

Kayser, H., 1976. Waste-water assay with continuous algal cultures: The effect of mercuric acetate on the growth of some marine dinoflagellates. - Mar. Biol. 36, 61-72.

Kayser, H., 1977. Effect of zinc sulphate on the growth of mono- and multispecies cultures of some marine plankton algae. - Helgoländer wiss. Meeresunters. 30, 682-696.

Klöckner, K., 1979. Uptake and accumulation of cadmium by Ophryotrocha diadema (Polychaeta). Mar. Ecol. Prog. Ser. 1, 71-76.

Kremling, K., Piuze, J., Bröckel, K. v. \& Wong, C. S., 1978. Studies on the pathways and effects of cadmium in controlled ecosystem enclosures. - Mar. Biol. 48, 1-10.

Leland, H. V., Luoma, S. N., Elder, J. F. \& Wilkes, D. J., 1978. Heavy metals and related trace elements. - J. Wat. Pollut. Control Fed. 50, 1469-1514.

Mang, S. \& Tromballa, H. W., 1978. Aufnahme von Cadmium durch Chlorella fusca. - Z. Pflanzenphysiol. 90, 293-302.

Markham, J. W., Kremer, B. P. \& Sperling, K.-R., 1980. Effects of cadmium on Laminaria saccarina in culture. - Mar, Ecol. Prog. Ser, 3, 31-39.

Prèvot, P. \& Soyer, M. O., 1978. Action du cadmium sur un Dinoflagellé libre: Prorocentrum micans E.: croissance, absorption du cadmium et modifications cellulaires. - C. r. hebd. Séanc. Acad. Sci., Paris (D) 287, 833-836.

Rosenthal, H. \& Sperling, K.-R., 1974. Effects of cadmium on development and survival of herring eggs. In: The early life history of fish. Ed. by J. H. Blaxter. Springer, Berlin. 383-396.

Rosenthal, H. \& Alderdice, D. F., 1976. Sublethal effects of environmental stressors, natural, and pollutional, on marine fish eggs and larvae. - J. Fish. Res. Bd Can. 33, 2047-2065.

Schmidt, D., 1976. Distribution of seven trace metals in sea water of the inner German Bight. C. M. I. C. E. S. C 10, 1-14.

Silverberg, B. A., 1976. Cadmium-induced ultrastructural changes in mitochondria of freshwater green algae. - Phycologia 15, 155-159.

Sperling, K.-R., 1977. Determination of heavy metals in seawater and marine organisms by flameless atomic absorption spectrophotometry. 6. Cadmium determination in culture waters from toxicological experiments with marine organisms. - Z. analyt. Chem. 287, 23-27.

Sperling, K.-R., 1978. Determination of heavy metals in seawater and in marine organisms by flameless atomic absorption spectrophotometry. 7. Simple extraction method for determination of extremely low cadmium levels in small seawater samples. - Z. analyt. Chem. 292, 113-119.

Sperling, K.-R., Bahr, B. \& Kremling, K., 1977. Schwermetallbestimmungen in Seewasser und in marinen Organismen mit Hilfe der flammenlosen AAS. 4: Beschreibung einer Routinemethode zur Bestimmung von Cadmium in kleinen Proben biologischen Materials. - Z. Lebensmittelunters.-Forsch. 163, 87-91. 
Taylor, D., 1977. A summary of the data on the toxicity of various materials to aquatic life. Vol. 2: Cadmium. Imperial Chemical Industries Ltd., Brixham.

Tkachenko, V. N., Mortina, S. V. \& Lukankina, E. V., 1974. The method of toxicological experiments and some results of toxicological effects of heavy metals on marine and freshwater monocell algae. - Trudȳ vses. nauchno-issled. Inst. morsk. rȳb. Khoz. Oceanogr. 100, 63-67.

Varma, M. M. \& Katz, H. M., 1978. Environmental impact of cadmium. - J. environ. Health 40, 308-314.

Westernhagen, H. v., Dethlefsen, V., Rosenthal, H., Fürstenberg, G. \& Klinkmann, J., 1978. Fate and effects of cadmium in an experimental marine ecosystem. - Helgoländer wiss. Meeresunters. 31, 471-484.

Yamagata, N., 1978. Cadmium in the environment and in humans. In: Cadmium studies in Japan: A review. Ed. by K. Tsuchiya, Kodansha, Tokyo, 19-43. 